Borisz Czekus $^{1}$

University John Naisbitt,

Faculty of Biofarming, Belgrade, Serbia
SCIENTIFIC REVIEW ARTICLE doi:10.5937/ekonomika1602179C

Received: March 9, 2016

Accepted: May 19, 2016

\title{
INFLUENCE OF STABILIZED SEWAGE SLUDGE ON THE YIELD OF POTATO (SOLANUM TUBEROSUM)
}

\begin{abstract}
The author has examined the application of different doses of stabilized-hydrated sewage sludge in two potato varieties in field conditions. Next to an unfertilized plot, he followed the growth, development and yield of varieties Agria and Aladin on soil treated with an amount of $50 \mathrm{t} / \mathrm{h}$ a and $30 \mathrm{t} / \mathrm{ha}$ of sludge from wastewater treatment plant in Subotica. He found that the highest yield was achieved at the variety Aladin (44.5 t/ha), when applying 30 t/ha of sludge. Agria produced 29.65 t/ha of tubers with the same amount of fertilizer. In both varieties the yields were higher on plots fertilized with 50 t/ha than on unfertilized soil. It was found that, in contrast to fertilizing with manure from $50 \mathrm{t} / \mathrm{ha}$, half the amount of stabilized sludge produced similar, if not higher yields. In the future it will be possible to substitute or supplement manure with stabilized sludge under controlled conditions.
\end{abstract}

Key words: potato, fertilization, stabilized sludge, yield, income

JEL classification: Q01, Q110

\section{УТИЦАЈ СТАБИЛИЗОВАНОГ ОТПАДНОГ МУЉА НА ПРИНОС КРОМПИРА (SOLANUM TUBEROSUM)}

\begin{abstract}
Апстракт
Ауторјеиспитиваоприменуразличитихдозастабилизованог-дехидратисаног отпадног муља код две сорте кромпира у пољским условима. Поред париеле без Ђубрена пратио је раст, развитак и принос сорте Агриа и Аладин на париелама третиране са количином од $50 \mathrm{~m} / \mathrm{xa}$ и $30 \mathrm{~m} / \mathrm{xa}$ муља са Суботичког пречистача отпадних вода.Установио је да се највећи принос (44,5 m/xa) остварује код сорте Аладин при примени $30 \mathrm{~m} / x а$ муља. Агриа је родила 29,65 m/xа кртола при истом количином ђубрења. Код обе сорте је био већи принос на париелама Ђубрене са $50 \mathrm{~m} /$ ха него на неђубренима.Установљено је да, насупрот Ђубрењу стајьаком од 50-60m/ха, упола мања количина стабилизованог муља продукује сличне приносе, ако не и веће.У будуће под контролисаним условима могућа ће бити замена или допуна стајског ђубрива са стабилизовании муљем.
\end{abstract}

Кључне речи: кромпир, Ђубрење, стабилизовани муљ, принос, приход

\footnotetext{
${ }^{1}$ borisz@82yahoo.com
} 


\section{Introduction}

In 2008 the European Community adopted directive 2008/98/EC, which regulates the disposal, recycling and distruction of industrial, municipal and hazardous waste. Based on this act, experts recommend an integrated and hierarchical scheme from minimization of waste until its final destruction (EC No. 2008/98 / EEC, Official Gazette of RS, 135/2004, 36/2009, 72/2009).

In developing countries, disposal and treatment of industrial and municipal wastewater are a large problem. In major cities in the Republic of Serbia, modern wastewater treatment plants are either already working or are under construction, but no municipality has a solution for unstable pressed sludge. The situation is the same in Subotica. The construction of a new treatment plant began in 2010. The recipient of purified water is Lake Palić, and solid waste is transported to the city dump. The dehydrated sludge is stored between the plant and the lake. The final deposition, further processing and use of sludge has not been resolved yet (Czekus, 2014b, p. 408; Jovičić, 2015).

The wastewater treatment plant in Subotica started working with new technology for purification of municipal and industrial wastewater in 2012. Due to this technology, the recipient (Lake Palić) now receives five to ten times less organic matter than before. Because the industry of the city is poorly developed, wastewater does not contain significant concentrations of heavy metals and impurities harmful to health. However, the resulting stabilized - pressed sludge from wastewater contains about $4.54 \%$ total nitrogen, $2.05 \%$ total phosphorus $\left(4.69 \% \mathrm{P}_{2} \mathrm{O}_{5}\right), 0.715 \%$ potassium $\left(0.858 \% \mathrm{~K}_{2} \mathrm{O}\right), 64.3 \%$ of organic compounds, and it is usable in crop production under controlled conditions (Czekus, 2014b, p. 408).

In 2013 the author conducted experiments with corn hybrid NS 640 in order to determine the potential of wastewater in Subotica - expressed in yield and profits. The first experimental plot was fertilized with pressed sludge from the treatment plant in Subotica, the second one with the same amount of cattle manure, whereas the control plot remained unfertilized. His assumption was that the nutritional value of sludge is at least as high as that of the best organic fertilizer used so far. The results confirmed his expectations. The yield of the plot treated with sludge was by $25 \%$ greater than the yield of the plot fertilized with manure in combination with artificial fertilizer (Czekus, 2014a, p. 81).

As a continuation of this project, he researched into the optimal amount of stabilized sludge in crop production and certain vegetable crops that shall be subject to heat treatment. As a result of his experiments with corn, he found that $50 \mathrm{t} / \mathrm{ha}$ of stabilized sludge provides a higher yield than the same amount of manure (Czekus, 2014, p. 329). The aim of this paper is to present the results of potato yield obtained from experimental plots fertilized with different amounts of stabilized sludge. The assumption was that even a smaller amount of this substance can generate as much yield as such as on plots fertilized with $50 \mathrm{t} / \mathrm{ha}$ of stabilized sludge. 


\section{Stabilized-dehydrated sludge}

Sludge separated from wastewater is digested in digesters at $33-37{ }^{\circ} \mathrm{C}$, with a retention time of at least 20 days. During this time, $80-85 \%$ of biogas is released. Anaerobic digestion reduces odors and the number of bacteria in the sludge, making it stabilized sludge that is relatively innocuous, harmless and has no odor. Stabilized sludge is drained into a special silo, from where it is sent to the filter press to separate the water. This sludge contains about $5-6 \%$ of dry matter. What comes out of the press is dehydrated, so-called pressed mud.

Sludge, as a by-product of wastewater, can be treated as a product and sold on the specialized market. Economical exploatation of sludge is an important aspect because by its placement wastewater companies not only get rid of material that occupies a large space, but also produce a revenue that reduces the operating costs of the company itself. It is also useful for the population, because its nutrients improve soil fertility in the long run, as opposed to artificial fertilizers, which provide high and stable yields of cultivated plants in the course of a year, but have a negative impact on soil fertility in the long run. In the short term they provide spectacular yields in the cultivation of plants, but after a while their harmful and devastating effects come to the fore (Cvijanović, 2013, p. 157, Cvijanović, 2016, p.132).

The best and final solution for the use of sludge would be a kind of processing, such as composting and briquetting. Sludge prepared this way could easily be stored and used for improving the qualities of light sandy soils of Subotica-Horgoš sands.

In 1986, the European Union adopted directive 86/278/EEC, which regulates the treatment of sludge and its application in agriculture. The primary aim of this law is to preserve the health of people and animals, as well as to protect the environment.

Direct use of sludge is allowed only in exceptional cases, otherwise it must be processed in some way. The seventh point of the Directive prohibits its use:

- on pastures, if grazing is planned within three weeks after dispersal,

- in orchards and vegetable gardens during the growing season,

- in vegetable cultivation, with plants whose fruit is used directly, without processing, ie. cooking.

In cases other than these, sludge can be used in plant production. Each member of the community regulates the use of dehydrated sludge in particular. The first factor in the issuance of permits for the application depends on the composition of the sludge. The main emphasis is placed on the concentration of heavy metals in the sludge. The geographical area where it would be applied, the crops that would be grown and the plants that inhabit the given area are also of importance.

The law obliges institutions applying sludge to examine its composition at least every six months. If the parameters of wastewater significantly change, the analysis should be carried out every three months. When carrying out the required analisys, the amount of dry matter, organic compounds, nitrogen, phosphorus, heavy metals and ph are to be examined (EC No. 2008/98/EEC). 


\section{Potato (Solanum tuberosum)}

In Serbia, the implementation of this type of organic fertilizer has not clearly been defined yet. Potato fertilization significantly affects the yield. The nutrition demand of potatoes is much greater than that of most cultivated plants. On average, a yield of $10 \mathrm{t}$ requires $48 \mathrm{~kg}$ nitrogen, $15 \mathrm{~kg}$ phosphorus and $85 \mathrm{~kg}$ of potassium (Lazić, 1998, p. 252).

In our country potatoes are grown on about about 110 thousand hectares. Its share of total arable land is $3.2 \%$. On the available land, the potato is the third most important food crop after corn and wheat. 870 thousand tons of potatoes, that is $80 \mathrm{~kg}$ per capita are produced each year. Within vegetable production in our country potatoes are the clear leader, with a share of $41 \%$ (Vlahović, 2003, p. 115).

It is an important and very widespread food product. More than 150 kinds of potatoes, which are used for the preparation of 700 various dishes, are produced worldwide for human consumption. In addition to being used in human nutrition, a certain amount of potatoes are used for the purposes of chemical, food and pharmaceutical industries, and as highly valuable forage. It is also used for the production of starch, alcohol, glucose, dextrin, rubber, glue and the like.

Therefore potatoes are used either as raw material for industry, or as human food that must be subject to heat treatment. For this reason, the experiment was carried out with potatoes.

\section{Material and Methods}

The experiment was carried out in Subotica on the author's own land, on black sand. It was not irrigated. The main meteorological parameters (Table 1) were obtained from the automatic weather station in the center of Subotica, located approximately 4 $\mathrm{km}$ from the experimental field. For this experiment, he used a Nexus instrument and the Weather Display software (www.sumeteo.info).

\begin{tabular}{|c|c|c|c|c|c|c|}
\hline Month/parameter & March & April & May & June & July & August \\
\hline precipitation $(\mathrm{mm})$ & 32,8 & 17,2 & 95,3 & 12,9 & 45,5 & 50,2 \\
deviation from the long-term average & $-3,2$ & $-21,4$ & $-13,6$ & $-36,2$ & $-17,9$ & $+5,8$ \\
\hline average monthly temperature $\left({ }^{\circ} \mathrm{C}\right)$ & 7,4 & 11,9 & 17,3 & 20,9 & 24,3 & 23,7 \\
deviation from the long-term average & $+0,2$ & $-1,0$ & $+0,5$ & $-0,1$ & $+0,9$ & $+1,0$ \\
\hline
\end{tabular}

Table 1: Meteorological parameters for Subotica 2015

From Table 1 we can see that in spring and summer months in Subotica the precipitation was lower than the monthly average in previous years. The deficit for these six months was $92.3 \mathrm{~mm}$. According to the statistics of the Republic Hydrometeorological Service of Serbia, the average amount of annual precipitation for this region is about 600 $\mathrm{mm}$ (www.hidmet.gov.rs). The monthly temperature averages ranged around the average of the past decades, although in summer 2015 there were 38 days when the average daily temperature was above $25^{\circ} \mathrm{C}$.

The experimental plot was divided into three equal parts. The first third was the control plot, that is, a plot without fertilization. The second part was treated with $3 \mathrm{~kg} /$ 
$\mathrm{m}^{2}(30 \mathrm{t} / \mathrm{ha})$ of stabilized sludge, and the third one with $5 \mathrm{~kg} / \mathrm{m}^{2}$, or $50 \mathrm{t} / \mathrm{ha}$ (Figure 1 ). The experiment was carried out with potato varieties "Agria" and "Aladdin", category $\mathrm{C} 2$, the first reproduction, calibration $35-55 \mathrm{~mm}$, produced in Serbia. The seed was not treated. The fifth reproduction of "Desiree" was also planted, but the results related to this variety are not the subject of this paper.

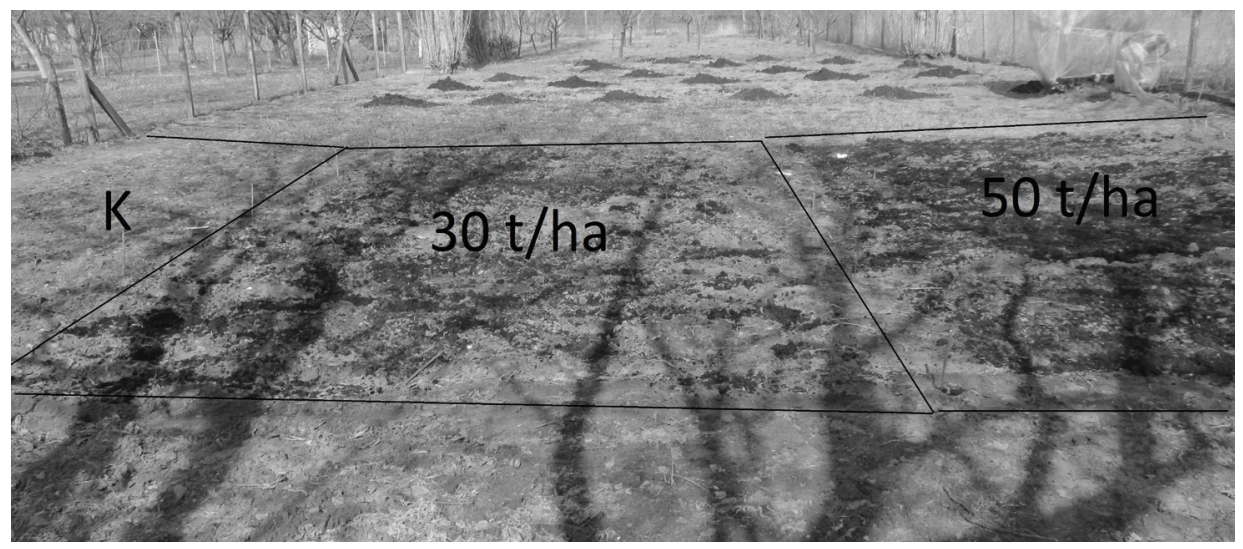

Figure 1. Various amounts of stabilized sludge

The preculture was peas (year 2014). The autumn tillage was conducted in October 2014 with a land milling machine, to a depth of about $25 \mathrm{~cm}$. After the spring frosts, the experimental field was divided into three equal parts (control plot, fertilization with 3 $\mathrm{kg} / \mathrm{m}^{2}$ and $5 \mathrm{~kg} / \mathrm{m}^{2}$ ). The composition of the pressed sludge was the following: $4.54 \%$ of total nitrogen, total phosphorus $2.05 \%\left(4.69 \% \mathrm{P}_{2} \mathrm{O}_{5}\right), 0.715 \%$ potassium $\left(\mathrm{K}_{2} \mathrm{O} 0.858 \%\right)$, $64.3 \%$ of organic compounds. After sowing preparations (milling-blending at a depth of $15 \mathrm{~cm}$ ) were carried out, the tubers were planted at a depth of 10-12 cm on March 21 . The distance between tubers within the row was $22-25 \mathrm{~cm}$, and the distance between rows was $50 \mathrm{~cm}$. For each type of fertilization and in both cultivars there were three repetitions. The distance between the individual varieties and plots was

$1 \mathrm{~m}$.

Care and protection of crops was conducted in accordance with the requirements (Tošev, 2002, p. 105). During the growing season, interrow processing was performed twice, and treatment against potato blight (caused by Phytophthora infestans) and the Colorado potato beetle (Leptinotarsa decemlineata) three times. Spray mixtures "Mospilan 20 SG" and "Antracol WP-70" were used for crop protection, $2.5 \mathrm{~g} / 10$ lit and 15-20 g/10lit respectively.

The harvest was carried out on the $171^{\text {st }}$ day of vegetation, on 8 September. Tubers from each plot were collected in special paper bags, and then classified and measured (Figure 2). 


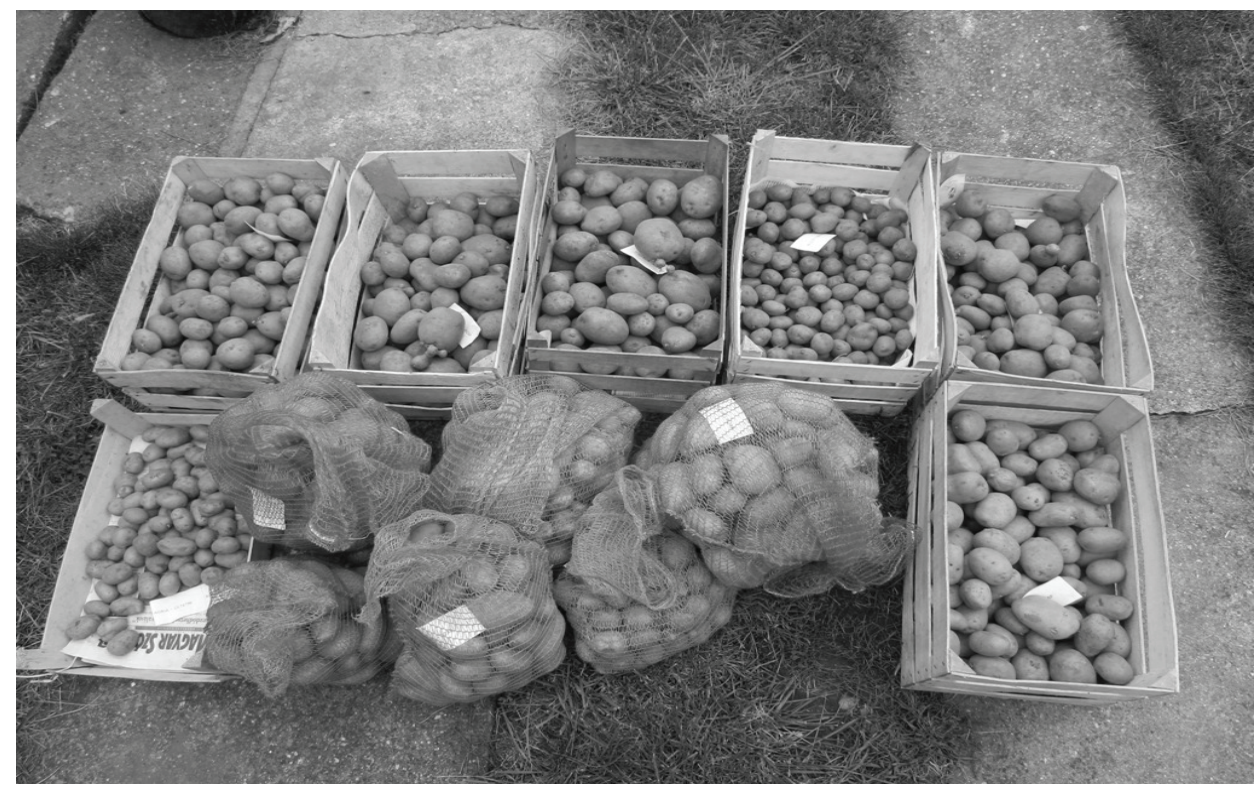

Figure 2. Part of the yield from the experimental field

Tubers were classified into three categories:

- Class I - physiologically ripe, normally developed and uniform in shape, size and colour. They are healthy, without sprouts, wrinkled or damaged crust. The tolerance of impurities and tubers infected by potato mold is up to $1 \%$.

- Class II - tubers have to be healthy and suitable for human consumption. $2 \%$ of impurities (soil or sprouts) are tolerated, and up to $10 \%$ of tuber weight of potatoes with imperfections that meet the minimum quality requirements. The amount of tubers with cracks, cuts, and bruises can be up to $5 \%$. The size of tubers must be at least such, that it is suitable for manual or automated peeling.

- $\quad$ small - useless, with a diameter less than $30 \mathrm{~mm}$, unripe, infected, cut apart or containing bite marks (Vlahović, 2003, p. 119).

After calibrating, each category was measured and recorded.

\section{Research results}

According to the latest data of the Republic Institute for Statistics of the Republic of Serbia, in 2014 the average yield of potatoes in Vojvodina was $17.00 \mathrm{t} / \mathrm{ha}$ (www. webrzs.stat.gov.rs). Two climatic factors, water and temperature are of crutial importance for the successful cultivation of potatoes and achieving high yields. When irrigated, tuber yield can reach up to 80 t/ha (Bročić, 2015), and in our calculations we took $30 \mathrm{t} /$ ha as expected yield (Đorđević, 2014).

In the municipality of Subotica, climatic conditions during the growing season were almost ideal for potato production. There was more than $260 \mathrm{~mm}$ of rainfall while 
the potatoes were in the soil (Table 1). When we add the winter precipitation, we get close to $300 \mathrm{~mm}$, and optimal precipitation for the successful production of medium-late and late varieties is about $460 \mathrm{~mm}$ (Bročić, 2015). The crucial point for this vegetation period was the temporal distribution of precipitation. It was far more favourable than in previous years, and thus compensated for the lack of spring moisture.

The total yield on the experimental plots in each type of treatment and in both varieties was far above the average in Vojvodina. The average yield of the three replications is given in Table 2.

\begin{tabular}{|l|c|c|}
\hline Sort & Agria & Aladin \\
\hline Control & 23,30 & 32,80 \\
\hline Average & 100,00 & 100,00 \\
\hline Index level & 34,30 & 49,65 \\
\hline $\mathbf{3 0}$ t/ha & 147,21 & 151,37 \\
\hline Average & 31,00 & 34,30 \\
\hline Index level & 133,05 & 104,57 \\
\hline $\mathbf{6 0}$ t/ha &
\end{tabular}

Table 2: Average tuber yield ( $\mathrm{t} / \mathrm{ha}$ )

The data in Table 2 clearly shows that the highest yield was achieved in the plots fertilized with $30 \mathrm{t} /$ ha of stabilized sludge. "Aladdin" has proven to be a higher-yielding variety. In treatment with

$30 \mathrm{t} /$ ha of stabilized sludge, it yielded $51 \%$ more than the unfertilized plots, while this figure in the variety 'Agria' was 47\%. Considering the data obtained from the plot fertilized with a double dose of sludge ( $50 \mathrm{t} / \mathrm{ha}$ ), we can see that the performance-fertility rate was reversed: "Agria" yielded a third more, and "Aladdin" only 5\% more.

The market of food products always requires high-quality goods. By removing small, damaged and diseased tubers from the total yield, we get a product that is suitable for placing on the market, ie. for human use. First-class and second-class tubers fall into this category (Vlahović, 2003, p. 110). The average yield of repetitions of edible potatoes (class I and class II) is given in Table 3.

\begin{tabular}{|l|c|c|}
\hline Sort & Agria & Aladin \\
\hline Control & 19,50 & 31,00 \\
\hline Average & 100,00 & 100,00 \\
\hline Index level & 3510 & 5580 \\
\hline Income & 29,65 & 44,50 \\
\hline $\mathbf{3 0}$ t/ha & 152,05 & 143,55 \\
\hline Average & 5337 & 8010 \\
\hline Index level & 26,65 & 29,65 \\
\hline Income & 136,67 & 95,65 \\
\hline $\mathbf{6 0}$ t/ha & 4797 & 5337 \\
\hline Average & Index level & \\
\hline Income &
\end{tabular}

Table 3: Average yield of edible tubers (t/ha) and the realized income ( $€$ ) of the same 
At the time of potato harvest, the price of potatoes in Serbia ranged between 20 $25 \operatorname{RSD}(0.18 €)$. The yield failed because of the drought, and the price of potatoes imported from the Czech Republic, Germany and Poland was about 30 cents, exclusive of transport costs. An increase in the price of this vegetable is yet to be expected (www. proberza.co.rs, www.pss-subotica.rs).

Calculating with only 18 euro cents per kilogram, the difference in the revenue in the plots fertilized with $30 \mathrm{t} / \mathrm{ha}$ and 50t/ha is $540 €$ in the case of the cultivar "Agria", and $2673 €$ in the case of cultivar "Aladdin" (Table 3). Stabilized sludge from the wastewater treatment plant in Subotica is not commercially available yet. It is used exclusively for experimental purposes, and to cover the city landfill.

As far as first and second class yield are concerned, their amount is by $5-16 \%$ less than the total yield, ie. the share unusable tubers is about $10 \%$ (Table 4). Expressed in percents, the control variety 'Agria' had the most waste (16.3\%), while on the plot "Aladdin", fertilized with 30 t/ha of dehydrated sludge, more than 5 tons of potatoes were unusable. Nevertheless, of the six parcels, this one produced the highest yield of consumable potatoes $(44.5 \mathrm{t} / \mathrm{ha})$.

\begin{tabular}{|c|c|c|c|c|c|c|}
\hline & \multicolumn{3}{|c|}{ Agria } & \multicolumn{3}{c|}{ Aladin } \\
\hline & $\sum$ & usable & not to be used & $\sum$ & usable. & not to be used \\
\hline $0 \mathrm{t} / \mathrm{ha}$ & 23,30 & 19,50 & $3,80(16,3 \%)$ & 32,80 & 31,00 & $1,80(5,5 \%)$ \\
\hline $30 \mathrm{t} / \mathrm{ha}$ & 34,30 & 29,65 & $4,65(13,6 \%)$ & 49,65 & 44,50 & $5,15(10,4 \%)$ \\
\hline $60 \mathrm{t} / \mathrm{ha}$ & 31,00 & 26,65 & $4,35(14,0 \%)$ & 34,30 & 29,65 & $4,65(13,6 \%)$ \\
\hline
\end{tabular}

Table 4: Share of consumption and unusable potatoes ( $t / h a)$

The data in Table 4 show that, when fertilizing with dehydrated sludge from 30 t/ha, variety "Aladin" produced $66 \%$ more than the variety 'Agria'. When it comes to fertilizing with a double dose of the above-mentioned sludge, the yield is lower, and the share of useless tubers is larger, up to $3 \%$ (Chart 1 ).

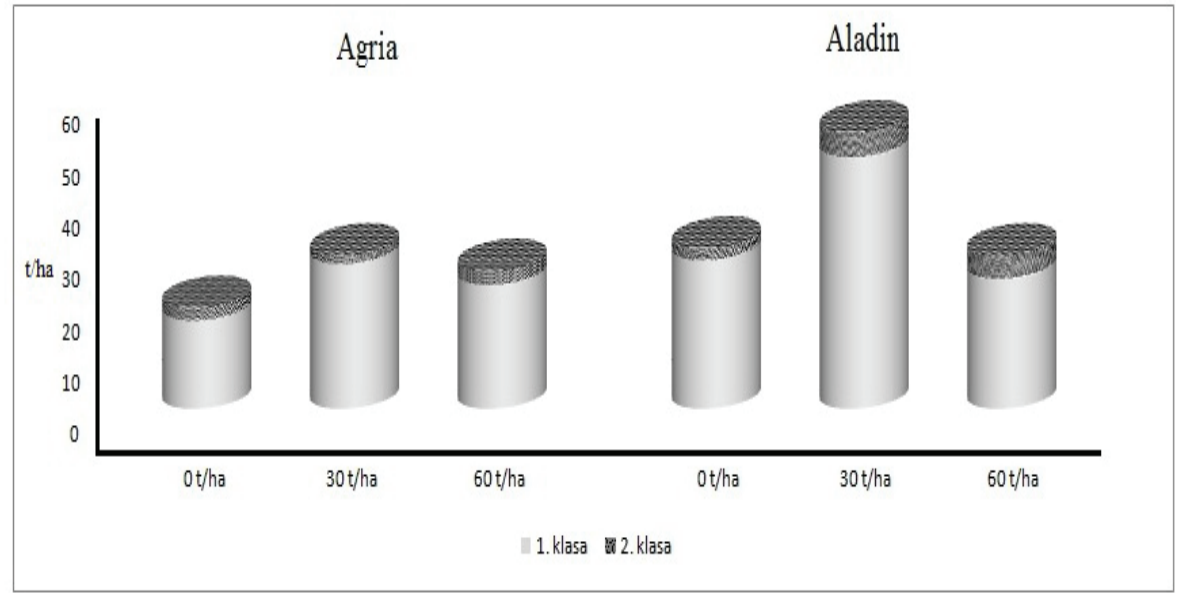

Chart 1: Total yield of two potato varieties with different doses of fertilization 


\section{Conclusion}

After grading the tubers, we came to the conclusion that in all three types of fertilization the variety "Aladin" gave higher yield under this year's weather- and agrotechnical conditions in Subotica. The highest yield of total and edible potato was on plots treated with $30 \mathrm{t} / \mathrm{ha}$ of dehydrated sludge. A slightly lower yield was obtained on the plots fertilized with double the amount of sludge and the lowest yield was obtained on the unfertilized plots.

The assumption was that a smaller amount (30 t/ha) of dehydrated sludge will generate similar yield as $50 \mathrm{t} / \mathrm{ha}$ of manure (or sludge), the amount used in modern vegetable production. The aim of the experiment was to find out if dispersing $50 \mathrm{t} / \mathrm{ha}$ of organic fertilizer of this type is economically viable, and whether a smaller amount would be enough as well. The hypothesis was confirmed, the goal was accomplished. Further experiments will specify the exact amount of sludge that gives the highest yield of first- and second class tubers.

In 2013, 1,600 containers ( $5 \mathrm{~m}^{3}$ each) of dehydrated sludge were pressed out at the wastewater treatment plant in Subotica. The net weight of sludge per container ranged from 2.5 to 3 tons. This amounts to about 4,500 tons of dehydrated sludge on an annual basis (Czekus, 2014c, p. 30). Calculating with $30 \mathrm{t} / \mathrm{ha}$ of sludge, this amount could be used to treat 150 hectares of potato crops. Today, due to more modern purification technology and larger wastewater quantities, $50 \%$ more dehydrated sludge is produced at the wastewater treatment plant in Subotica.

In Vojvodina, as well as in the whole region in this part of Europe, the number of livestock and livestock farms is decreasing rapidly, which means that the amount of first class organic fertilizer ie. manure decreases. After composting and maturing, this sludge would be a very good fertilizer for vegetable farming, horticulture and for improving soil fertility - obviously with a continuous monitoring of its composition.

\section{References}

Bročić, Z. (2015). Navodnjavanjem krompira do 80 tona po hektaru. Poljoprivredni list, 55.

Council Directive (EC) No 2008/98/EEC of 19. 11. 2008, official Journal of the European Communities (At: ec.europa.eu/environment/waste/framework, (Januar 2015.)

Cvijanović, G., Dozet, G., Cvijanović, D. (2013). Menadžment u organskoj biljnoj proizvodnji. Beograd, Institut za ekonomiku poljoprivrede Beograd.

Cvijanović, G., Savić, S. (2016). Zaštita ekosistema i bioremedijacija. Beograd, Institut za ekonomiku poljoprivrede Beograd.

Czekus, B. (2014a). Uticaj presovanog mulja iz Subotičkih otpadnih voda na prinos kukuruza. In: P. Bogdanović (Ed.), Međunarodna konferencija Otpadne vode, komunalni čvrsti otpad i opasan otpad, 2014 (pp. 81-85). Zlatibor: Udruženje za tehnologiju vode i sanitarno iženjerstvo. 
Czekus, B. (2014b). Uticaj prečišćenih industrijskih i komunalnih otpadnih voda na kvalitet vode jezera Palić. In: S. Komatina (Ed.), IV Međunarodni kongres Biomedicina i geonauke - uticaj životne sredine na zdravlje ljudi, 2014 (pp. 408420). Beograd: Asocijacija geofizičara i ekologa Srbije.

Czekus, B., Gligor, G. (2014). Mogućnost korišćenja stabilizovanog-presovanog mulja kao đubriva u proizvodnji kukuruza. In: S. Komatina (Ed.), IV Međunarodni kongres Biomedicina i geonauke - uticaj životne sredine na zdravlje ljudi, 2014 (pp. 329-336). Beograd: Asocijacija geofizičara i ekologa Srbije.

Czekus, B. (2014c). Potencijal biološko aktivnog mulja subotičkih otpadnih voda. 38. Smotra naučnih radova studenata poljoprivrede $i$ veterinarske medicine sa međunarodnim učešćem, 2014 (pp. 30-34). Novi Sad: Poljoprivredni fakultet.

Đorđević, M. (2014). Sadnja krompira i kalkulacija proizvodnje 2014. At: www. zdravasrbija.com, 20. 01. 2016.

Jovičić, N. (2015). Verbal presentation. JKP “Čistoća i Zelenilo”, Subotica.

Lazić, B., Đurovka, M., Marković, V., Ilin, Ž. (1998). Povrtarstvo. Novi Sad, SR: Univerzitet u Novom Sadu, Poljoprivredni Fakultet, Novi Sad.

Tošev, M. (2002). Rasprostranjenost i suzbijanje otpornih vrsta korova u ratarskim kulturama. Revija Agronomska saznaja, (13) 6.

Vlahović, B. (2003). Tržište poljoprivredno-prehrambenih proizvoda. Novi Sad, SR: Univerzitet u Novom Sadu, Poljoprivredni Fakultet, Novi Sad.

Zakon o zaštiti životne sredine, Službeni glasnik RS, br. 135/2004, 36/2009, 72/2009.

Zakon o upravljanju otpadom, Službeni glasnik RS, br. 36/2009.

www.hidmet.gov.rs. Republički hidrometeorološki zavod Srbije, official web presentation, oktober 2015.

www.sumeteo.info. Automatska meteorološka stanica, Subotica, 05. 09. 2015.

www.webrzs.stat.gov.rs. Republički zavod za statistiku Republike Srbije, official web presentation. 01. 02. 2016. 